\title{
ファジー理論を用いた岩盤分類の構成方法に関する研究
}

\section{A STUDY ON ROCK MASS CLASSIFICATION BY FUZZY SET THEORY}

\author{
清 水則一*・桜井春輔** \\ By Norikazu SHIMIZU and Shunsuke SAKURAI
}

\begin{abstract}
This paper presents a method of constituting a rock mass classification, which is capable of representing an engineer's subjectivity on engineering judgement and thought process by using the fuzzy set theory. The method is composed of three parts ; (1) description of judging classification parameters by fuzzy sets, (2) grading of importance of each parameter, (3) total evaluation of judgement of all parameters by fuzzy integral. The classification provides a distribution of "fuzzy expected values" covering all the rock mass classes (five classes, i. e. "very good", "good", "fair", "poor" and "very poor", are adopted in this paper). An example is shown to illustrate the constitution of rock mass classification by the proposed method.
\end{abstract}

\section{1. まえがき}

岩盤分類は, 岩盤の工学的特性を特徴付ける地質・力 学的要因を現位置において観察あるいは計測し, 一定の 規準に従って岩盤を類別し，岩盤の良好度を評価するも のである．そして，分類結果は岩盤物性，あるいは，標 準施工法などに対応付けられ，設計・施工における技術 的判断のために利用される.

現在, 数々の優れた岩盤調査法, および, 解析法が開 発されている. しかし, 現段階において, 岩盤内の応力 や岩盤の工学的特性を定量的に求めることは技術的・経 済的な制限から困難であり，また，現場観察や計測結果 の評価法，および，設計における解析手法についても， 信頼できる方法がまだ確立されていないことを考える と, 岩盤分類は, 岩盤構造物の設計・施工において, 欠 くことのできない重要なものである．このような状況の もとで，国の内外においてこれまでに，ダム・橋梁など の基礎, トンネル・地下空洞，および，斜面など，構造 物別に多数の岩盤分類が提案されている11.

* 正会員 工修 神戸大学助手 工学部土木工学科 （甬657 神戸市灘区六甲台町 1-1）

** 正会員 工博, Ph. D. 神戸大学教授 工学部土木工学科 (同上)
しかし, 分類要因の評価基準や, 岩盤の区分または等 級の境界が明確でないこと, および, 岩盤に対する評価 の程度が個人によって異なることから，岩盤分類の結果 は技術者の個人的な感覚・主観に左右されるとの指摘が ある.もちろん，結果に個人的な差異が生じないように， 分類要因の判定区分を定量的に表示し，分類結果を客観 的に点数などで与える分類法も提案されている21,3).

しかし, 分類要因が岩盤の評価に及ぼす影響の程度や, 判定結果の総合的評価において，それらを客観的かつ定 量的に表わせるほど岩盤力学の理論が確立しているわけ ではない，実際には，定量的表現であっても，それらは 岩盤分類を作成する技術者の経験に基づいた主観的な判 断に負うところが大きい.したがって，岩盤分類には分 類作成者の主観が本質的に含まれているものと考えられ る.

そこで, 岩盤分類を構成するとき, 従来の分類のよう に, 主観性を排除して, すべてにおいて客観的に評価す る方向を目指すのではなく, 工学的に有用な主観につい ては，これを利用する立場をとることがよいと考える.

本論文では, このような立場から, 岩盤分類を“ファ ジー（あいまい）理論”を利用して構成する方法を提案 する.なお, ファジー理論とは, 人間の主観にかかわる あいまいさを数学的に表現するために提案されたファ 
ジー集合論,および,これを基礎において考案されたファ ジー推論, ファジー関係, ファジー代数, および, ファ ジー積分などの総称である.

\section{2. ファジー集合とファジー積分}

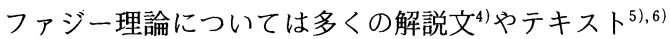
があるので, ここでは, 本論文で用いるファジー集合, および，ファジー積分についてのみ簡単に述べておく.

\section{（1）ファジー集合}

ファジー集合は，人間の主観にかかわるあいまいさを

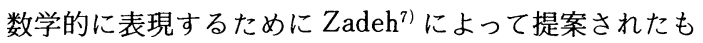
のである.

通常の集合論では, 個々の要素がその集合に属すか属 さないかは明確に規定される.すなわち，ある全体集合 $U$ の要素 $u(u \in U)$ が集合 $H(H \subset U)$ に属するかどうか は，特性関数 $\chi_{H}(u)$ によって規定される.

$$
\chi_{H}(u)= \begin{cases}1 & u \in H \\ 0 & u \notin H\end{cases}
$$

一方，ファジー集合論では， $u \in U$ が集合 $A$ に属する 程度を, $[0,1]$ の值をとる帰属度関数 (membership function) $\mu_{A}(u)$ を用いて表わす.

$$
\mu_{A}(u): U \rightarrow[0,1]
$$

ただし， $\mu_{A}(u)$ は，1に近ければ， $u$ が $A$ に属する程度 が大きく，0に近ければ，逆に小さいことを意味する. このような集合 $A$ をファジ一集合という.つまり，ファ ジ一集合は, ある要素がそれに属するかどうかの程度が

$[0,1]$ の值で規定される境界のぼやけた，あいまいな 集まりのことである.なお，式（1）および（2）より 明らかなように,通常の集合はファジ一集合に含まれる.

また，帰属度関数は集合 $A$ のあいまいさを定量表現 するものと解釈できる. 帰属度関数の形は主観的に定め るものであるが, 標準となる関数も与えられている ${ }^{8)}$.

ファジー集合 $A$ は, 要素 $u$ が連続, あるいは, 離散 的な場合について, 一般に, それぞれ, 次のように表現 される4).

$$
\begin{aligned}
& A=\int_{V} \mu_{A}(u) \mid u \\
& A=\sum_{i} \mu_{A}\left(u_{i}\right) \mid u_{i}
\end{aligned}
$$

\section{（2）ファジー積分}

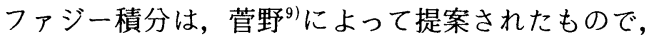
次式によって定義される.

$$
f h \circ g \equiv \bigvee_{i=1}^{N}\left[h\left(u_{i}\right) \wedge g\left(F_{i}\right)\right]
$$

ただし， $U=\left\{u_{1}, u_{2}, \cdots, u_{N}\right\}, \quad F_{i}=\left\{u_{1}, u_{2}, \cdots u_{i}\right\}$ である. 被積分関数 $h\left(u_{i}\right)$ は $[0,1]$ の値をとり, $h\left(u_{1}\right) \geqq h$

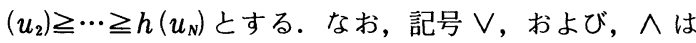
それぞれ最大值および最小值を取ることを意味する.ま
た, $g\left(F_{i}\right)$ はファジー测度 ${ }^{9)}$ で次の性質をもつ。

( i ) $g(\phi)=0, g(U)=1$

(ii ) $\quad F_{i} \subset F_{j} \rightarrow g\left(F_{i}\right) \leqq g\left(F_{j}\right) \cdots$

ただし，

ファジー積分は，あいまいな問題の主観的総合評価に 利用される.

\section{3. ファジー理論による岩盤分類の構成}

技術者の主観を取り入れることのできる岩盤分類を構 成するには，主観の導入箇所，および，その表現方法を 明確にすることが重要である，本論文では，主観の導入 䇢所を明確にするため, 岩盤分類を次の三段階に分けて 構成する.

（1）分類要因の判定区分の設定一一各分類要因につ いて，評価のための言語変数や区分の境界を設定する.

（2）分類要因の重要度の設定一一分類結果に及ぼす 影響の程度に応じて, 分類要因の重要度を設定する.

（3）総合評価一一分類要因の判定結果と重要度に基 ゔき,岩盤分類を行うための総合的な評価方法を定める.

これらの各段階において導入される主観性を表現する ためファジー理論を用いる．本章では，以上の考えに基 づく岩盤分類の構成方法について述べる，なお，完全な 岩盤分類を構成するためには，分類要因の選定方法や分 類結果と設計・施工との対応について考察する必要があ るが，本論文は岩盤分類を構成するための方法を論ずる ことが目的なので,ここではこれらについて言及しない.

\section{（1） 分類要因の判定区分の設定}

現行の岩盤分類では，主に表一1に示すような分類要 因が用いられている．これらの要因の判定区分は定性的 あるいは定量的に，また，両者を併記して表現される. しかし，定性的区分はもちろんのこと，定量的区分にお いても，区分の境界は明確でなく，その設定根拠はあい まいである．図一1に新鮮な岩石の一軸圧縮強度の数々 の評価基準 ${ }^{10)}$ 示すが，同じ表現でも提案者によって， かなりばらつきのあることがわかる，このことは，評価 基準の言語（たとえば，“strong”や“high”など）の 定義が技術者によって異なることを示している.した

\begin{tabular}{|c|c|}
\hline 定珄的表現 & 定量的表 現 \\
\hline 岩石の種 類 & 弾性波速度 \\
\hline ハンマー打撃 & 一軸王縮強度 \\
\hline 割れ目状態 & 割れ目間隔 \\
\hline 風 化 の 程 度 & $\begin{array}{lll}R & Q & D\end{array}$ \\
\hline 湧 水の程 度 & 涌 水 量 \\
\hline
\end{tabular}
がって，判定区分の設定は，これを明確に設定できる理 論や基準がない現状では, 最終的に岩盤分類の作成者の 主観に依存することになる.

\section{表一1 主な分類要因}




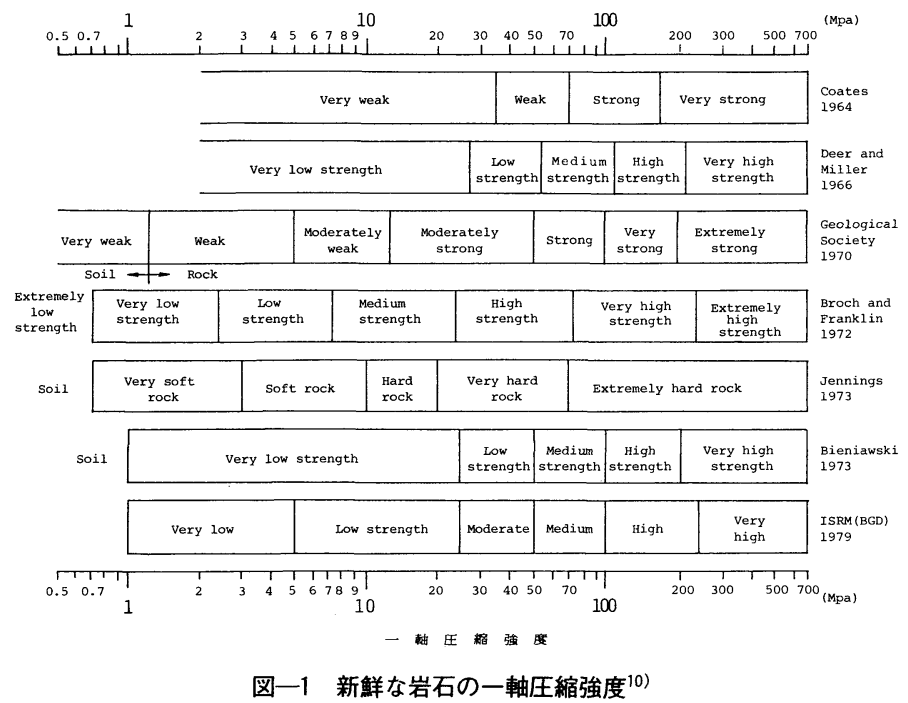

以上の理由によって, ここでは, 分類要因の判定区分 の境界はあいまいなものとして, 判定区分を区間 $[1,5]$ のファジー集合として表現する.ただし, 本研究では, 簡単のため $[1,5]$ を $N$ 等分し，次のように全体集合 を定める.

$$
C_{N}=\{1,0,1.0+h, 1.0+2 h, \cdots,
$$

$$
1.0+(N-2) h, 5.0\} \quad(N \geqq 2)
$$

ただし， $h=4 /(N-1)$ である. 全体集合 $C_{N}$ の要素は岩 盤の状態の良い悪いを表わすグレード（grade）を意味 する. すなわち， 1.0 および 5.0 は，それぞれ，岩盤の 最も悪いグレード，および，最も良いグレードである. また,これらの中間の要素値は, 両極の中間の状態を表 わすグレードである.

次に, 分類要因の判定区分をファジー集合として定義 する. まず，分類要因を記号 $X_{i}(i=1,2, \cdots, M ; M$ は 分類要因の数）と表わしておく. 各分類要因について, 5 段階の評価区分を設定し，これらをファジ一集合 $X_{i k}$ $(k=\mathrm{I}, \mathrm{II}, \mathrm{III}, \mathrm{I}, \mathrm{V})$ と書く.ただし， $X_{i k}$ の帰 属度関数を $\mu_{x_{t} k}\left(c_{n}\right)\left(c_{n} \in C_{N} ; c_{n}=1.0+(n-1) h\right)$ と表 わす．また，判定区分を表わす添字 $k$ は，岩盤の性質 に良い影響を与えると考えられるものから順に I， II， III, IV, Vと付けるものとする.

たとえば, 分類要因 $X_{j}$ を「割れ目間隔」として, こ の判定区分をファジー集合として表現すると次のように なる. 判定区分の言語変数 (目安として数值も併記) を, “非常に広い(約 $200 \mathrm{~cm}$ 以上)”, “広い(約 60 200 cm)”, “中程度（約 20 60 cm)”, “狭い（約 6 20 cm)”, “非 常に狭い（約 $6 \mathrm{~cm}$ 以下）”で表わす. $N=9$ の場合, こ れらの判定区分は次のようにファジー集合として定義で きる.
$X_{j I}=“ I$. 非常に広い” $=0.5|4.5+1.0| 5.0$

$X_{j \mathrm{II}}=“$ II . 広い” $=0.5|3.5+1.0| 4.0+0.5 \mid 4.5$

$X_{j \mathbb{I I}}=$ “III. 中程度” $=0.5|2.5+1.0| 3.0+0.5 \mid 3.5$

$X_{j \mathrm{~V}}=“ \mathrm{IN}$. 狭い" $=0.5|1.5+1.0| 2.0+0.5 \mid 2.5$

$X_{j \mathrm{~V}}=“ \mathrm{~V}$. 非常に狭い” $=1.0|1.0+0.5| 1.5$

以上のように，ファジー集合を用いれば，境界のあい まいな判定区分が定量的に表現される。帰属度関数は岩 盤分類作成者の主観によって定められるものであり，こ の関数によって, 作成者の考えを分類要因の判定区分に 反映させることができる.

\section{（2）分類要因の重要度の設定}

岩盤分類の結果に及ぼす分類要因の影響の程度は, 各 分類要因の判定区分ごとに異なると考えられる．たとえ ば, 同じ “中程度” の判定であっても,「岩石強度」と「割 れ目間隔」とでは分類結果への影響度は異なる.さらに, 影響度は同じでも, 分類要因の判定結果の信頼度が異な る場合も考えられる。ここでは，これらの影響度，およ び, 信頼度を総合して分類要因の重要度とよび, 分類要 因の判定区分ごとに重要度係数として $[0,1]$ の值を与 える. 重要度係数は分類作成者の主観に基ついて定めら れるものである. なお, 分類要因 $X_{i}$ の判定区分 $k$ に対 する重要度係数は $W_{i k}$ と表わしておく.

\section{(3) 総 合評価}

各分類要因の判定結果から最終的な岩盤分類に至る過 程には, 分類作成者の主観が関与するが,一般に,この 過程は岩盤分類に明記されていない. そのため, 岩盤分 類を利用する技術者にとって，分類表あるいはその注釈 から分類作成者の思考過程を読み取ることは難しく, し たがって, 岩盤分類を適用する際, 苦慮する場合もある. ここでは,この過程を明確に表現するために,ファジー 
積分を用い, 数式によって岩盤の総合評価を行う方法を 示す.

\section{a ) ファジ一集合としての “対象岩盤”}

まず, 分類要因の判定結果と重要度係数を用いて, 分 類しようとする岩盤を “対象岩盤”というファジー集合 として表現する.すなわち, 全体集合 $C_{N}$ の各要素 $c_{n}$ が “対象岩盤”に属している程度を表わす帰属度関数 $\mu_{R}\left(c_{n}\right)$ を, $\mu_{x_{i} k}\left(c_{n}\right)$ と $W_{i k}$ を用いた演算式によって定め る.たとえば，各分類要因について，5段階に分けた判 定区分の帰属度関数を各分類要因に対して共通とすれ ば，次のような演算式によって $\mu_{R}\left(c_{n}\right)$ を定めることが できる.

$$
\mu_{R}\left(c_{n}\right)=\vee_{k=\mathrm{I}}^{\mathrm{v}}\left(W_{k} / W\right) \mu_{x_{i} k}\left(c_{n}\right)
$$

ただし，

$$
\begin{aligned}
& W_{k}=\sum_{i=1}^{M} W_{i k t} \delta\left(k, k_{i}\right), \\
& W=\bigvee_{k=1}^{\mathrm{v}} W_{k}
\end{aligned}
$$

である. また, $\delta\left(k, k_{i}\right)$ は $k=k_{i}$ のとき $1, k \neq k_{i}$ のと き 0 とする. なお, $k_{i}$ は分類要因 $X_{i}$ の判定結果の区分 番号 ( I, II, III, IN, Vのいずれか) である.もちろ $h, \mu_{R}\left(c_{n}\right)$ を定める演算式は上式が唯一のものではなく, 分類作成者の感覚および経験になじむように主観的に定 めればよい.

b ) 評 価尺度

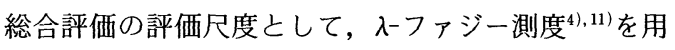
いる. $\lambda$-ファジー測度は, $\lambda$ をパラメーターとして, 次 のように構成される ${ }^{11}$.

$$
\begin{aligned}
& g_{\lambda}\left(F_{1}\right)=g^{1} \\
& g_{\lambda}\left(F_{i}\right)=g^{i}+g_{\lambda}\left(F_{i-1}\right)+\lambda g^{i} g_{\lambda}\left(F_{i-1}\right) \\
& \quad(-1<\lambda<\infty) \quad(i=2,3, \cdots, N)
\end{aligned}
$$

ただし， $F_{i}=\left\{c_{1}, c_{2}, \cdots, c_{i}\right\}$ である.また， $g^{i}$ はファジー 密度 ${ }^{4)}\left(0 \leqq g^{i} \leqq 1\right)$ であり, 適当に与えることができるが, 次の式を満足しなければならない11).

$$
1=\left\{\begin{array}{lc}
\sum_{i=1}^{N} g^{i} & (\lambda=0) \\
(1 / \lambda)\left[\prod_{i=1}^{N}\left(1+\lambda g^{i}\right)-1\right] & (\lambda \neq 0)
\end{array} .\right.
$$

上式は $\lambda$ と $g^{i}$ の制限式であり, $\lambda$ をえる場合, 式 (11) を満足するように $g^{i}$ に適当な定数を乗じて,$g^{i}$ を規格 化する必要がある.

いま, $g^{i}$ を, 岩盤のグレード $c_{i}$ を重視する度合と考 えれば, 式 (10) によって構成される $g_{\lambda}\left(F_{i}\right)$ は, $\lambda$ を パラメーターとし， $F_{i}$ を重視する度合を表わす評価尺 度となる、この評価尺度においては，入の值を変化させ て, 主観性を次のような意味で導入できる.つまり, $\lambda>0$ のとき, $g_{\lambda}\left(F_{i}\right) \geqq g^{i}+g_{\lambda}\left(F_{i-1}\right)$ となり, $F_{i}$ を重視
する度合は $F_{i-1}$, および， $c_{i}$ をそれぞれ重視する度合 の和より大きいことを意味し， $\lambda<0$ のさきはの逆で ある. $\lambda=0$ のとき, $g_{\lambda}\left(F_{i}\right)=g^{i}+g_{\lambda}\left(F_{i-1}\right)$ となり, 重要 視する度合は加法的で, $\lambda$-ファジー測度は確率測度に 一致する.

\section{c ）ファジー積分による総合評価}

岩盤の総合評価は, 岩盤の評価区分の帰属度関数を被 積分関数とするファジー積分によって行う.すなわち， 岩盤の評価区分を“非常に良い”，あるいは“悪い”な ビという言語変数によって表現し，それぞれの評価区分 を $C_{N}$ におけるファジー集合 $Z_{j}(j=1,2, \cdots, J ; J$ は評価 区分の数) として定め, これらの帰属度関数 $\mu_{z j}\left(c_{n}\right)$ を ファジー積分の被積分関数とする.ただし， $\mu_{z j}$ $\left(c_{1}^{(j)}\right) \geqq \mu_{z_{j}}\left(c_{2}^{(j)}\right) \geqq \cdots \geqq \mu_{z_{j}}\left(c_{N}^{(j)}\right)$ となるように $c_{n}$ の順番を 並べ換え, $C_{N}^{(j)}=\left\{c_{1}^{(j)}, c_{2}^{(j)}, \cdots, c_{N}^{(j)}\right\}$ を定めておく必要があ る.

$\lambda$ ーファジー測度 $g_{\lambda}\left(F_{i}\right)$ を求めるために, ファジー密 度 $g^{i}$ を次式のように定める.

$$
g^{i}=\alpha^{(j)} \mu_{R}\left(c_{i}^{(j)}\right)
$$

ただし， $\alpha^{(j)}$ は $g^{i}$ を規格化する定数で，パラメーター を与えた後, 式 (11) より求められる.

総合評価のためのファジー積分を $j=1,2, \cdots, J$ に対 して，次のように定義する.

$$
F I(j)=f \mu_{z_{j}} \circ g_{\lambda}=\bigvee_{i=1}^{N}\left[\mu_{z j}\left(c_{i}^{(j)}\right) \wedge g_{\lambda}\left(F_{i}^{(j)}\right)\right]
$$

ただし， $F_{i}^{(j)}=\left\{c_{1}^{(j)}, c_{2}^{(j)}, \cdots, c_{i}^{(j)}\right\}$ である.ここで, $F I(j)$ は, $\lambda$ を小さくすると， $c_{n}^{(j)}$ の中で $n$ の小さい值（岩盤の評 価区分 $Z_{j}$ の帰属度関数の值が大きいグレード）に対応 する $\mu_{R}\left(c_{n}^{(j)}\right)$ を重視する結果を与える．逆に， $\lambda$ を大き くすると, $c_{n}^{(j)}$ の $n$ の大きい值に対応する $\mu_{R}\left(c_{n}^{(j)}\right)$ を重 視する結果を与える.

ファジー積分 $F I(j)$ は, 分類要因の判定結果と重要度 係数から定めるファジー測度を主観的な評価尺度とし て, 対象岩盤が各評価区分 $j$ に属するファジー的な期 待度（その值をファジー期待値とよぶ）を表わすものと 考えられる. 最終的な岩盤分類の結果は, 各岩盤の評価

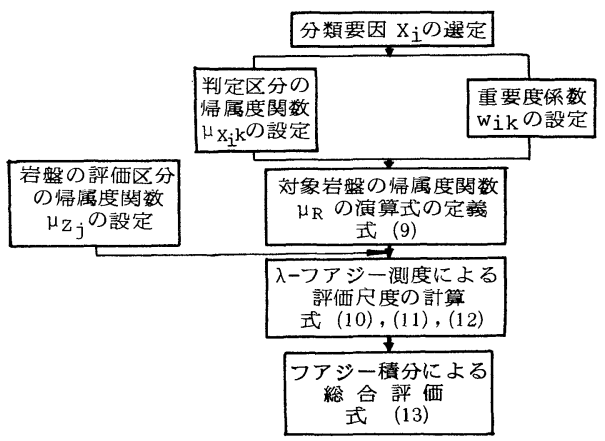

図一2提案する岩盤分類の構成手順 
区分に対するファジー期待值の分布として求められる.

図一2 は，ここで提案した岩盤分類の構成手順である. なお，本岩盤分類をファジ一岩盤分類 (Rock Mass Classification by Fuzzy Set Theory; RMCF) とよぶ ことにする.

\section{4. ファジー岩盤分類の具体例}

前章で示した岩盤分類の構成方法の具体例として, Bieniawski の Geomechanics Classification (RMR シ ステム：表一2参照 $)^{2), 12)}$ を参考にしてトンネルのファ ジー岩盤分類を図一2の手順に従って作成する.

1）分類要因 $X_{i}$ の選定：ファジー岩盤分類の分類要 因として RMR システムと同じ要因を用いる（表一 3 , $X_{1} \sim X_{6}$ 参照).

2）判定区分の帰属度関数 $\mu_{x_{i} k}$ の設定：まず，各分 類要因の判定区分をそれぞれ，5段階の言語変数によっ て表わす (表一3参照). 次に, 判定区分 $\mathrm{I} \sim \mathrm{V}$ に対し て䚻属度関数を与え，これらをファジ一集合とする. 帰 属度関数は岩盤分類作成者の経験や知識に基づき主観的 に定めるものであるが，ここでは，標準関数多を用いて， 図一3のように定める。なお，図一3には，全体集合を $C_{9}(N=9)$ とした場合の帰属度関数を○で示している.

3) 重要度係数 $W_{i k}$ の設定：重要度係数は原位置岩 盤の性状に基づき，岩盤分類作成者の経験や知識によっ て主観的に定めるものであるが，ここでは，割れ目状態 の重要度が最も高いとして, 表一4のように与えられた ものとする.なお，各分類要因において重要度係数は一 定とした.

4）岩盤の評価区分の帰属度関数 $\mu_{z j}$ の設定：岩盤の 評価区分は “I．非常に良い”, “II. 良い”, “吕. 普通”, “IV. 悪い”, “V. 非常に悪い” の 5 段階とする. そして, これらをファジー集合 $Z_{j}(j=1,2.3,4,5)$ と定義する.
帰属度関数 $\mu_{z j}\left(c_{n}\right)$ は, $j=1,2,3,4,5$ について, それぞ れ，図一3で示した I V V 同じ関数を用いる.

\section{表一3 ファジー岩盤分類の分類要因と判定区分}

\begin{tabular}{|c|c|c|c|c|c|c|}
\hline & 因 判定 & 1 & 1 & III & N & $r$ \\
\hline$x_{1}$ & 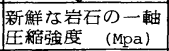 & $\begin{array}{l}\text { 非常に大きい } \\
(>250)\end{array}$ & $(100-250)$ & & $125=$ & $\begin{array}{c}\text { 非常に小さい } \\
(25>)\end{array}$ \\
\hline & $\begin{array}{l}R \underset{(z)}{Q} \text { D } \\
(z)\end{array}$ & & 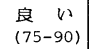 & \begin{tabular}{|l|} 
普 通 \\
$(50-75)$
\end{tabular} & \begin{tabular}{|l} 
贯 \\
$(25-50)$
\end{tabular} & $\begin{array}{l}\text { 非常に覀い } \\
(25>)\end{array}$ \\
\hline$x_{3}$ & $\begin{array}{c}\text { 割れ目間隔 } \\
(\mathrm{cm})\end{array}$ & $\begin{array}{l}\text { 非常に広い } \\
(>200)\end{array}$ & $\begin{array}{c}\text { 広 } \\
(60-200)\end{array}$ & & \begin{tabular}{|l} 
狭 \\
$(6-20)$
\end{tabular} & $\begin{array}{l}\text { 非常に狭い } \\
(6>)\end{array}$ \\
\hline$x_{4}$ & 割れ目状態 & 非常に良い & $w$ & 普 通 & 雭 & 非常に腎い \\
\hline & 湧水状況 & 乾 & た & れた & 滴 水 & 流 \\
\hline & 方 向 & 監 & & 普 & 不 利 & 非常に不利 \\
\hline
\end{tabular}
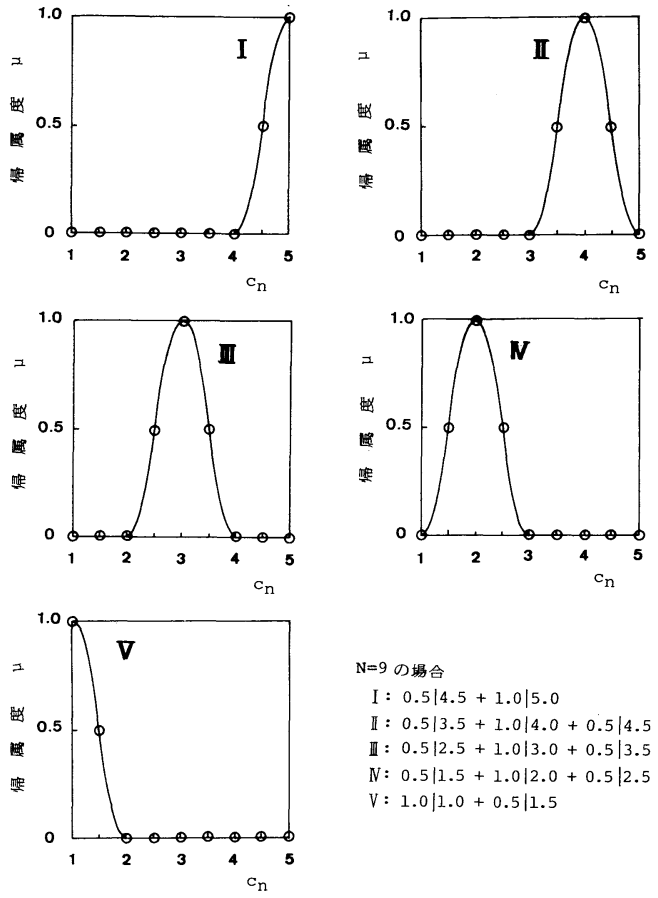

$\mathrm{N}=9$ の場合

$I: 0.5|4.5+1.0| 5.0$

II $: 0.5|3.5+1.0| 4.0+0.5 \mid 4.5$ III $: 0.5|2.5+1.0| 3.0+0.5 \mid 3.5$ $\mathrm{N}: 0.5|1.5+1.0| 2.0+0.5 \mid 2.5$ $V: 1.0|1.0+0.5| 1.5$

表一2 RMR システム (Bieniawski ${ }^{12)}$ より一部抜粋)

\begin{tabular}{|c|c|c|c|c|c|c|}
\hline \multicolumn{7}{|c|}{ 分類要因とその評点 } \\
\hline & 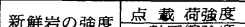 & $>10 \mathrm{Mpa}$ & $4 \sim 10 \mathrm{Mpa}$ & $2 \sim 4$ Mpa & $1 \sim 2 \mathrm{Mpa}$ & 一軸王綰強度を使用 \\
\hline & 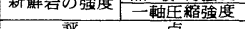 & $>250 \mathrm{Mpa}$ & $100 \sim 250 \mathrm{Mpa}$ & $50 \sim 100 \mathrm{Mpa}$ & $25 \sim 50 \mathrm{Mpa}$ & $\begin{array}{|lll|}5 \sim 25 & 1 \sim 5 & 1 \text { Mpa } \\
2 & 1 & 0\end{array}$ \\
\hline & 点 & 15 & 12 & 7 & 4 & 10 \\
\hline \multirow{2}{*}{2} & $\begin{array}{lll}R & Q & D \\
\end{array}$ & $90 \sim 100$ & $75 \sim 90$ & $50 \sim 75$ & $25 \sim 50$ & $25>$ \\
\hline & 評 & 20 & 17 & 13 & 8 & 3 \\
\hline & 不連続面の閪滑 $(\mathrm{cm})$ & $>200$ & $60 \sim 200$ & $20 \sim 60$ & $6 \sim 20$ & $6>$ \\
\hline & 評 点 & 20 & 15 & 10 & 8 & 5 \\
\hline & 不連 続面の 状態 & $\begin{array}{l}\text { 非常に粗い表面 } \\
\text { 分離せす } \\
\text { 未風化 } \\
\text { 連続せす } \\
\end{array}$ & $\begin{array}{l}\text { わすかに粗い表面 } \\
\text { 分離幅 <1 mm } \\
\text { わすかに風化 }\end{array}$ & \begin{tabular}{|l|} 
わずかに粗い表面 \\
分離湢<1 mm \\
極めて風化
\end{tabular} & 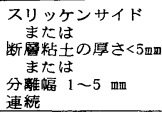 & 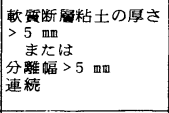 \\
\hline & 点 & 30 & 25 & 20 & 10 & 0 \\
\hline & 通状 $\mid$ トンネル10m当りの涌水量 & またはなし & $\frac{10 \quad 1 / \mathrm{mim}}{0.0 \sim 0.1}$ & $\frac{10 \sim 251 / \min }{0.1 \sim 0.2}$ & $25 \sim 1251 / \mathrm{min}$ & $1251 / \min <$ \\
\hline & 水況 & 完全に乾燥 & 湿亏t & $0.1 \sim 0.2$ & 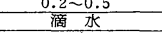 & $\frac{0.5<}{\text { 流 水 }}$ \\
\hline & 評 点 & 15 & 10 & 7 & 4 & 0 \\
\hline \multicolumn{7}{|c|}{ B. 不連続面の方向に対する補正評点 } \\
\hline \multicolumn{2}{|r|}{ 節理の方向・傾斜 } & 非常に有利 & 直 利 & 普 通 & 不 利 & 非常に不利 \\
\hline \multirow{2}{*}{\multicolumn{2}{|c|}{ 評 点 }} & 0 & -2 & -5 & -10 & -12 \\
\hline & & $\frac{0}{0}$ & $\begin{array}{l}-2 \\
-5\end{array}$ & $\begin{array}{r}-7 \\
-25\end{array}$ & $\begin{array}{l}-15 \\
-50\end{array}$ & $\frac{-25}{-60}$ \\
\hline \multicolumn{7}{|c|}{ C. 総合評点か 5 決め5れる岩盤等粄 } \\
\hline & 評点 & $100-81$ & $80-61$ & $60-41$ & $40-21$ & $20>$ \\
\hline & 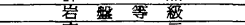 & 1 & $\mathbb{1}$ & III & N & $\mathrm{V}$ \\
\hline & 㞷宗 & 非常に首好な岩盤 & 良好な铬船 & 普通の岩盤 & 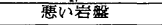 & 非常に惠い岩 \\
\hline
\end{tabular}




\section{表一4 重要度係数}

\begin{tabular}{|c|c|c|c|c|c|}
\hline $\mathrm{i} \backslash \mathrm{k}$ & $\mathrm{I}$ & II & II & N & V \\
\hline 1 & 0.5 & 0.5 & 0.5 & 0.5 & 0.5 \\
\hline 2 & 0.7 & 0.7 & 0.7 & 0.7 & 0.7 \\
\hline 3 & 0.7 & 0.7 & 0.7 & 0.7 & 0.7 \\
\hline 4 & 1.0 & 1.0 & 1.0 & 1.0 & 1.0 \\
\hline 5 & 0.5 & 0.5 & 0.5 & 0.5 & 0.5 \\
\hline 6 & 0.4 & 0.4 & 0.4 & 0.4 & 0.4 \\
\hline
\end{tabular}

表 5 例題 (1)

$\begin{array}{ll}\text { (a) 分類要因 } & \text { (b) R M R システム }\end{array}$

\begin{tabular}{|c|c|c|c|c|c|}
\hline \multicolumn{2}{|r|}{ 分類 要 因 } & \multicolumn{2}{|c|}{ 判 定 } & 評点 & $\begin{array}{c}\text { フアジー岩盤分類 } \\
\text { のための判足 }\end{array}$ \\
\hline 1 & $\begin{array}{l}\text { 新鮮な岩石の } \\
\text { 一軸圧䊉強度 }\end{array}$ & & Mpa & 12 & II. 大きい \\
\hline 2 & $R Q D$ & 70 & $\%$ & 13 & 11. 普通 \\
\hline 3 & 割れ目間隔 & 50 & $\mathrm{~cm}$ & 10 & II. 中程 度 \\
\hline 4 & 割れ目状驡 & $\begin{array}{l}\text { わずか } \\
\text { 分 離 } \\
\text { わず }\end{array}$ & 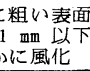 & 25 & II. 良 い \\
\hline 5 & 湧水状 況 & 滴 & 水 & 4 & N. 滴 水 \\
\hline 6 & $\begin{array}{l}\text { 構造物と割れ目の } \\
\text { 方 関 保 }\end{array}$ & 不 & 利 & -10 & N. 不利 \\
\hline & & & $R M R$ & 54 & \\
\hline & & & 評 価 & Fair & \\
\hline
\end{tabular}

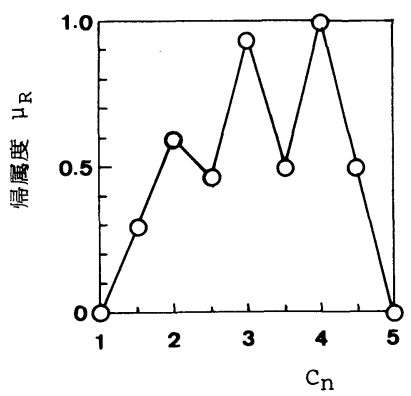

図一4 “対象岩盤” の帰属度関数

いま, 例題 ( 1 ) として, 表一5のように判定された 岩盤注)に対してファジ一岩盤分類を適用する.なお, 全 体集合は， $C_{9}(N=9)$ とする.

5）“対象岩盤” の帰属度関数 $\mu_{R}$ : ファジー集合とし ての “対象岩盤” の帰属度関数 $\mu_{R}$ を式（9）によって 求めれば図一4のようになる.

6）ファジー積分による総合評価：4）で与えた岩盤 の評価区分の帰属度関数と5）において求めた“対象岩 盤” の帰属度関数 (図一4) を用いてファジー積分を行う. 図一5は $\lambda=0$ の場合のファジー積分である. 図中実線 は岩盤の評価区分の帰属度関数（ファジー積分の定義に 従って值の大きい順に記入されている）であり，点線は 式 $(10)$ （12）を用いて計算された גーファジー測度で ある.ファジー積分の值は式（13）に従えば，図中の矢

注）この例題は, 文献 13）から引用した。 ただし，そこでは, 当時の分類表 ${ }^{13)}$ を用いているため, 69 点 (Good) と評価 されているが，本論文では新しい分類表（本文の表一2） を用いて評点を算出した.

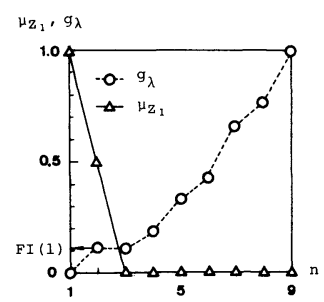

(a) FI(1)

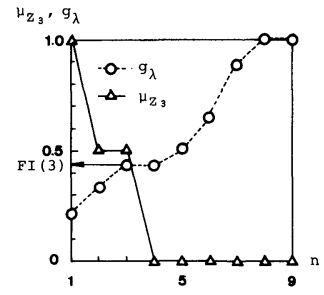

(c) FI (3)

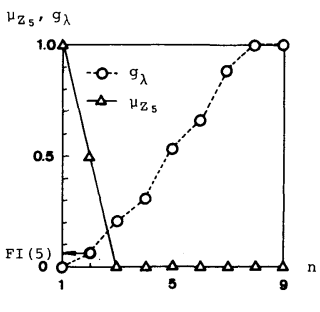

(e) FI (5)

図一5 ファジー積分 $(\lambda=0$ の場合 $)$

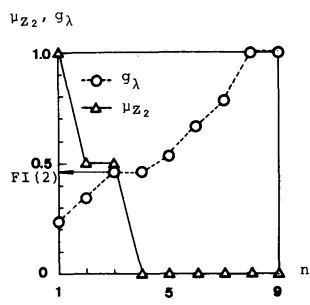

(b) FI (2)

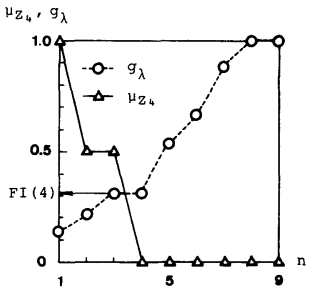

(d) FI (4)
印の位置の縦軸の読みとして求められる.

結局, 例題（1）に対して, 本ファジ一岩盤分類の結 果は，図一6に示すように岩盤の評価区分に対するファ ジ一期待值の分布として求められる. 図一 6 から, 対象 岩盤は“II．良い”，および，“吕．普通”に属する期待 度がほぼ同程度であることが示される，しかし，岩盤が 他の評価区分に属する可能性が全くないわけではなく, その程度がファジー期待值によって表わされている. ま た，入を小さくすると，前に述べたように，岩盤の評価
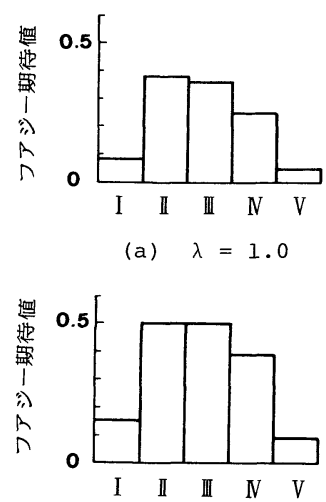

(c) $\lambda=-0.5$ (a) $\lambda=1.0$

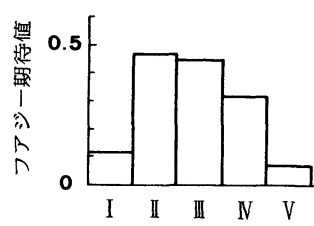

(b) $\lambda=0.0$
岩盤の評価区分

I：非常に良い

II: 良い

III: 普 通

N : 悪

V : 非常に悪い
図一6 例題（1）に対するファジー岩盤分類の結果 
区分の州属度関数の值が大きいグレードを重視すること になり,ファジー期待值の值が全体に大きくなっている. なお，ここでは $\lambda=1.0,0.0,-0.5$ の 3 ケースの結果 を示したが，実際の適用においては，原位置の岩盤の状 態を最も適切に表現する分類結果を与える $\lambda$ の值を採 用すればよい。

\section{5. 考察}

提案したファジー岩盤分類において，技術者の主観は

(1) 分類要因の判定区分

(2) 分類要因の重要度

(3) 岩盤の評価区分

(4) 総合評価

の各設定段階において導入される. (1) (4)に含まれる主 観性は，ファジー集合，および，ファジー積分を用いる ことで, 定量的，あるいは，数式によって表現できる.

3.において，これらの設定について述べたが，そこで 述べた設定の方法は唯一ではない．唯一ではないからこ そ，自由に主観を導入することができるのである．ただ し, 本論文でいうところの主観は, 技術者の十分な知識, 経験，実績，および，考察に裏付けられたものでなけれ ばならないことはいうまでもない.

(1) (4)を定量的にあるいは数式を用いて表現すれば, 岩盤分類を構成する思考の過程が客観的に定式化される ことになる，一般に，岩盤分類は，岩盤の成因・産状・ 種類，および，構造物の種類・規模などに対して適用範 囲があるにもかかわらず，その範囲が明確でないため, 提案されている分類方法をそのまま適用すると，対象岩 盤に必ずしもなじまない場合がある．しかし，岩盤分類 を構成する際の思考過程が客観的な形で表現されている と，状況に応じて，岩盤分類を利用する技術者の手で修 正することが可能となる．ファジー岩盤分類は，そのよ うな分類の枠組みを与えるものである．たとえば，判定 区分の帰属度関数や重要度係数などを適当に与え，実際 に適用しながら，個々の現場になじむように修正するこ とができる。

現行の岩盤分類の大部分では，分類結果は 1 つの評点 あるいは等級として与えられるので，分類結果において 対象岩盤の特徵が平均化される.これに対して，本岩盤 分類では，分類結果は，図一6に示すように評価区分に 対するファジー期待值の分布として求められ，分類要因 の判定結果が直接, 分類結果に反映される.たとえば, 表一6に示す岩盤の場合 (例題 $(2)$ ), 分類要因の判定 は“良い”側と“悪い”側に分散しているが，RMR は 55 となる. つまり, RMR システムの判定結果は, 分 類要因の判定結果を平均したものとなっている. 一方, 本ファジー岩盤分類では，図一7のようなファジー期待
表-6 例題 (2)

$\begin{array}{ll}\text { (a) 分 類要因 } & \text { (b) } \mathrm{RMR} \text { システム }\end{array}$

(c) R M C F

\begin{tabular}{|c|c|c|c|c|c|}
\hline \multicolumn{2}{|r|}{ 分 類 要因 } & \multicolumn{2}{|c|}{ 判 定 } & 評点 & $\begin{array}{c}\text { フアジー岩盤分類 } \\
\text { のための判定 }\end{array}$ \\
\hline 1 & $\begin{array}{l}\text { 新鮮な岩石の } \\
\text { 一軸压緥强度 }\end{array}$ & \multicolumn{2}{|c|}{30 Мра } & 4 & N.小さい \\
\hline 2 & $\mathrm{R} Q \mathrm{D}$ & \multicolumn{2}{|c|}{$80 \%$} & 17 & II. 良W \\
\hline 3 & 割れ目間隔 & \multicolumn{2}{|c|}{$100 \mathrm{~cm}$} & 15 & II. 広W \\
\hline 4 & 割れ目状態 & \multicolumn{2}{|c|}{$\begin{array}{l}\text { わずかに粗い表面 } \\
\text { 分 離 } 1 \mathrm{~mm} \text { 成 } \\
\text { わずかに風化 } \\
\end{array}$} & 25 & II. 良 い \\
\hline 5 & 涌水状況 & 滴 & 水 & 4 & $N$. 滴 水 \\
\hline \multirow[t]{3}{*}{6} & $\begin{array}{c}\text { 構造物と割れ目の } \\
\text { 方向の関係 }\end{array}$ & \multirow[t]{3}{*}{ 不 } & 利 & -10 & N. 不利 \\
\hline & & & $\mathrm{R} M \mathrm{R}$ & 55 & \\
\hline & & & 評 価 & Fair & \\
\hline
\end{tabular}

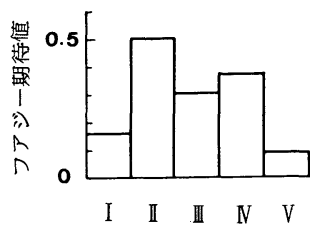

図一7 例題（2）に対するファジー岩盤分類の 結果 $(\lambda=0$ の場合 $)$

值の分布を得る．この結果は，分類要因の判定結果を直 接反映したものとなっており，岩盤の評価において多価 的な情報を与えるものと考えられる.

\section{6. むす び}

本論文では，技術者の主観や思考過程を取り扱うこと のできる岩盤分類の構成方法を提案した。ここで得た知 見を以下にまとめる.

（1）岩盤分類の構成を(1)分類要因の判定区分の設 定，(2)分類要因の重要度の設定，(3)総合評価の方法の設 定の三段階に分け，それぞれの段階において，ファジー 理論を用いれば，岩盤分類は定量的あるいは数式表現さ れる.

（2）ファジー理論を用いれば，岩盤分類の構成の思 考過程を数式化することができ，岩盤分類に内在する主 観性を客観的に示すことができる。

（３）本ファジ一岩盤分類において，技術者の主観に よって設定するものは，(1)分類要因の判定区分の帰属度 関数，(2)分類要因の重要度係数，(3)岩盤の評価区分の帰 属度関数，(4)対象岩盤を表現する帰属度関数を導く演算 式，(5)評価尺度におけるパラメーター ように, 分類作成者が決定できる自由度が多いため,ファ ジ一岩盤分類は，幅広い岩盤の種類，および，構造物に 適用できる可能性がある.

（4）ファジー岩盤分類の分類結果は，岩盤の各評価 区分に対するファジ一期待值の分布として与えられるた め，情報量の多い分類結果となる. 
岩盤分類は実務に結び付いてこそ価値があるのはいう までもない，本岩盤分類の現場への適用性を調査すると 同時に，分類結果と設計・施工の結び付けを行うことが 今後の課題となろう.

なお，ファジ一理論は，技術者（専門家）の主観的な 判断や思考過程を定量的に表現できる新しい方法論とし て, 多くの分野で注目されている ${ }^{14)}$. 土木工学において, ファジー理論は，構造工学などの分野においてすでに適 用され，成果を上げているが(15) 17), 岩盤工学においては, 研究の緒についたばかりである ${ }^{18), 199}$. 岩盤工学では, 技 術者の十分な実績に基づいた主観的判断は特に重要であ り, 主観性を取り扱えるこの新しい方法論の活躍の場は 非常に広いと考える.

1) 日本応用地質学会編：岩盤分類, 日本応用地質学会, 1984.

2) Bieniawski,Z. T. : Geomechanics Classification of Rock Masses and Its Application in Tunneling, Proc. 3rd Int. Congress on Rock Mechanics, Vol. II-A, pp. 27 -32, 1974.

3) Barton, N., Lien; R. and Lunde, J. : Engineering Classification of Rock Masses for the Design of Tunnel Support, Rock Mechanics, Vol.6, No.4, pp.189 236, 1974.

4）菅野道夫：あいまい理論 [I]～[IN], 計測と制御, Vol. 22, No. 1, pp. $171 \sim 174$, No. 4 , pp. $380 \sim 384$, No. 5, pp. 454 458, No. 6, pp. 554 559, 1983.

5）浅居喜代治・C.V. Negoida 編：あいまいシステム理論 入門, オーム社, 1978.
6）西田俊夫・竹田英二：ファジィ集合とその応用, 森北出 版, 1978.

7) Zadeh, L. A. : Fuzzy Sets, Information and Control, Vol. 8, pp. 338 353, 1965.

8) 水本雅晴: 最近の Fuzzy 集合理論, 数理科学, No. 191, pp. 15 20, 1979 .

9）菅野道夫：Fuzzy 測度と Fuzzy 積分, 計測自動制御学会 論文集, 第 8 巻, 第 2 号, pp. 218 226, 1972.

10) Bieniawski, Z. T. : Rock Mechanics Design in Mining and Tunneling, Balkema, pp. 100, 1984.

11）菅野道夫：Fuzzy 測度の構成と Fuzzy 積分によるパター ンの類似度評価, 計測自動制御学会論文集, 第 9 巻, 第 3 号, pp. 361 368, 1973.

12）文献 10)，pp.112１20，ただし，和訳は文献 1）pp.169 を参考にした。

13) Hoek, E. and Brown, E. T. : Underground Excavations in Rock, The MAA Publishing Company, pp. 27, 1981.

14）浅居喜代治・田中英夫：ファジィシステム分野の発展と 現状，計測と制御，Vol.24, No. 5, pp. 465 467, 1985.

15) Brown, C. B. and Yao, J. T. P. : Fuzzy Sets and Structural Engineering, Journal of Structural Engineering, ASCE, Vol. 109, No. 5, pp. 1211 1225, 1983.

16）白石成人・古田 均: ファジィ集合論の構造工学への応 用, 土木学会誌, Vol.69, No.6, pp.63 67, 1984.

17）西村 昭・藤井 学・宮本文穂：道路橋 $\mathrm{RC}$ 床版の診断 と評価に関する基礎的研究, 材料, 第 34 巻, 第 376 号, pp. 40 46, 1985.

18) Fairhurst, C. and Lin, D. : Fuzzy Methodology in Tunnel Support Design, Proc. 26 th US Symposium on Rock Mechanics, Vol.1, pp. 269 278, 1985.

19) Nguyem, V. U. and Ashworth, E. : Rock Mass Classification by Fuzzy Sets, 文献 18), pp. 937 945.

(1985.12.4 • 受付) 